\title{
The sustenance of growing and fattening ruminants by intragastric infusion of volatile fatty acid and protein
}

\author{
BY E. R. ØRSKOV, D. A. GRUBB, G. WENHAM \\ AND W. CORRIGALL \\ The Rowett Research Institute, Bucksburn, Aberdeen $A B 29 S B$ \\ (Received 23 June 1978 - Accepted 27 October 1978)
}

\begin{abstract}
A technique is described for feeding young sheep for long periods entirely by the infusion of volatile fatty acids into the rumen and protein and other essential nutrients into the abomasum. When the energy infused was twice the estimated requirement for maintenance, growth rate and nitrogen retention were essentially the same as in normally-fed sheep.
\end{abstract}

There are several principles of the nutrition of ruminants which are difficult to study because their diets are fermented to yield volatile fatty acids (VFA). The VFA can vary both in the amounts produced and in composition, and both can vary during a feeding cycle. The rumen micro-organisms produce microbial protein in varying amounts and the dietary protein is degraded by rumen microbes to varying extents (Ørskov, I977). Several attempts have been made to infuse known quantities of VFA and protein. At the maintenance feeding level, Armstrong \& Blaxter (I957 $a$ ) infused VFA for short periods as the only source of energy. Also Martin \& Blaxter (1963) infused protein and Armstrong \& Blaxter (1956 $b$ ) glucose as the only nutrients for fasting sheep.

Infusion of VFA at higher levels was attempted by Armstrong \& Blaxter (1957b) and Ørskov \& Allen (1965) fed increments of salts of VFA with concentrate diets. These latter studies suffer from the disadvantage of possible interference of the VFA, or their salts, with the digestion and metabolism of the basal diet since it was only achieved when the animals were given a basal diet of solid food, and even with that regimen only small additions of VFA or VFA salts were possible. Attempts to sustain long-term infusion of VFA alone have generally been abandoned owing to problems of electrolyte imbalance and acidity of rumen contents. Tao \& Asplund (1975), however, have recently sustained lambs at maintenance energy levels for periods of some weeks by infusion of partially-neutralized VFA and buffer solutions into the rumen, and amino acids into the abomasum, but they also reported several problems and deaths due to electrolyte imbalance.

The method reported here was developed to sustain ruminants at high feeding levels and maintain normal growth by complete intragastric infusion.

\section{EXPERIMENTAL}

The following is a description of the infusion technique as it was developed after several attempts which failed. Since, however, the blood composition and rumen $\mathrm{pH}$ were measured routinely it was possible when an animal showed signs of severe stress or died to make an appropriate change in the procedure. The first attempts failed because VFA alone was infused as a result of which the animal developed, after some days, a severe acidosis. Other attempts failed as a result of partially neutralizing the VFA with sodium hydroxide. Toxic levels of sodium in the blood in excess of $200 \mathrm{mmol} / \mathrm{l}$ were observed. It was finally realized that the rumen $\mathrm{pH}$ and blood electrolytes could be kept in the normal range provided a 
buffer based both in quantity and composition on saliva was infused separately from the VFA and with a separate terminal in the rumen. A total of ten lambs was used to develop the technique.

\section{Surgical preparations}

The lambs were fitted with vulcathene rumen cannulas, made at the Rowett Institute, of internal diameter approximately $14 \mathrm{~mm}$ (McKenzie \& Kay, 1968). The cannulas were exteriorized between the last rib and the lumbar transverse processes. For the abomasal infusion a transparent polyvinyl tube was used (Portex Ltd, Hythe, Kent). The tube was approximately $0.4 \mathrm{~m}$ long with $4 \mathrm{~mm}$ internal and $7 \mathrm{~mm}$ external diameter. A circular flange, $20 \mathrm{~mm}$ in diameter and $2 \mathrm{~mm}$ thick was made from polyethylene sheeting and glued (Portex Vinyl Cement; Portex Ltd, Hythe, Kent), to the end of the catheter (see Fig. I). An incision was made within a 'purse-string' suture midway between the greater and lesser curvature on the right lateral wall of the abomasum, the flanged end of the catheter was inserted and the 'purse-string' tightened. Subsequently a second flange was pushed down the catheter so that the abomasal wall was contained between the two flanges (see Fig. I). A collar of $7 \mathrm{~mm}$ internal diameter and with I I mm external diameter was brought hard up against the second flange and glued in position. This provided a very secure and leak-proof abomasal entry. The free end of the catheter was exteriorized by passing the catheter through the eye of a large needle and puncturing the body wall from within just below the lumbar processes. To ensure that the tube was not pulled directly from outside it was securely anchored to the wool of the sheep.

\section{Infusion procedure}

A multichannel flow inducer (Watson Marlow MC/Io; Watson Marlow Ltd, Falmouth, Cornwall) was used and the speed adjusted to infuse the daily allowance in $23 \mathrm{~h}$. The length of the tubing inside the rumen cannulas was approximately $150 \mathrm{~mm}$ to ensure that the infusates were added directly to the rumen fluid. In order to prevent the strong acid solution from affecting the rumen wall, a small polyethylene cylinder, Io $\mathrm{mm}$ diameter and $30 \mathrm{~mm}$ long, was glued to the end of the infusion tubes so that rumen fluid entered the cylinder and diluted the acids (see Plate I).

Before infusion began approximately six plastic pan scrubbers were inserted into the rumen via the cannula (see Plate I $(a)$ ). A similar type has been used by Dr J. G. Gordon (unpublished results). These had the effect of maintaining motility and of continually abrading the rumen papillas. Plate $\mathrm{I}(b)$ shows the rumen wall of a lamb which was given intraruminal infusion and no food by mouth for 2 months. When the lambs were slaughtered the pan scrubbers were recovered and used again. The development of the infusion procedure was facilitated by continual monitoring of the metabolic state of the animals. The $\mathrm{pH}$ of rumen contents was determined twice daily. Blood samples were taken twice weekly and sometimes more frequently for estimation of $\mathrm{Na}$, potassium calcium, magnesium, inorganic phosphorus, blood sugar and ketones by standard methods. Erythrocytes and white blood cells were estimated together with packed cell volume and haemoglobin concentration. When the problems referred to earlier were solved, no abnormalities developed other than those that might be expected from experimental constraints.

\section{Casein}

The casein was dissolved in warm water to which $2 \mathrm{M}$-sodium carbonate was added to give a final casein solution of $2.5 \mathrm{l} / \mathrm{d}$. The level of casein used was calculated to give $\mathrm{I} \cdot 4 \mathrm{I} g$ $\mathrm{N} / \mathrm{kg}$ body weight $\left(\mathrm{W}^{0.75}\right)$ per day at twice maintenance energy level, with the same porportion to energy at lower infusion rates. It was given via the abomasal catheter as continuous infusion. 


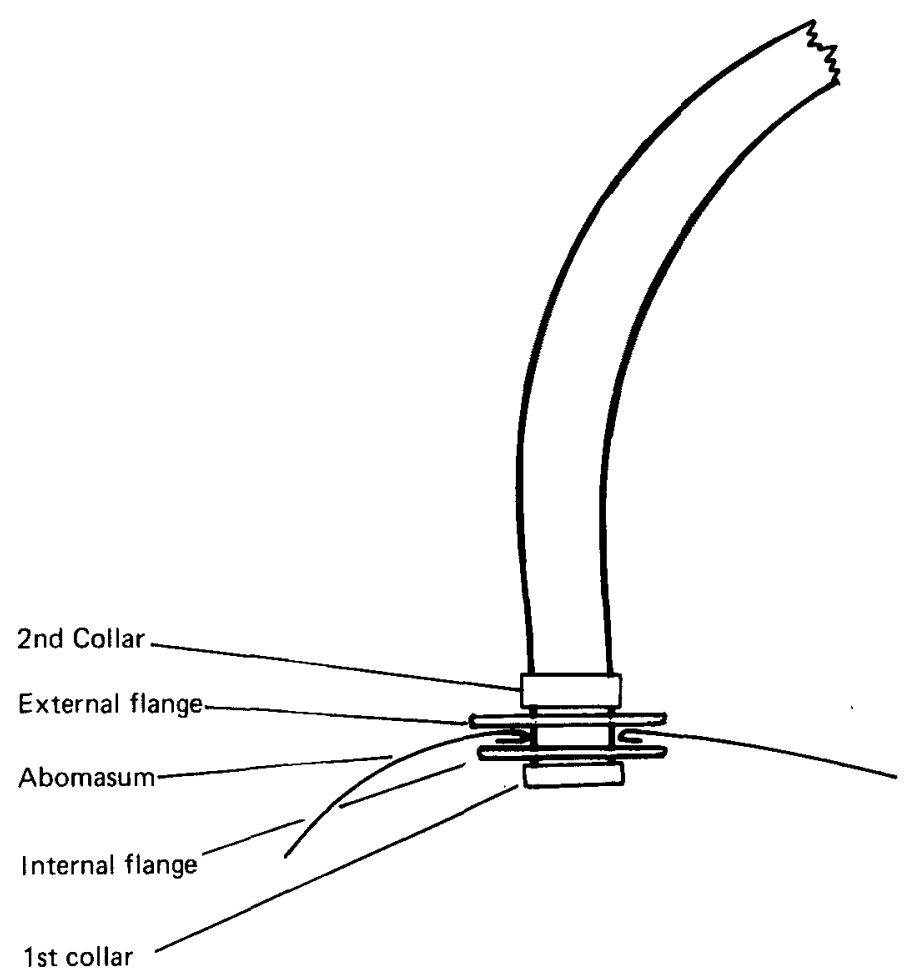

Fig. I. The method of securing the abomasal catheter to abomasal wall.

$V F A$

The VFA were given in several molar proportions indicated in Table 2 . The VFA, together with the major minerals were given as a final solution of $2.5 \mathrm{l} / \mathrm{d}$. It was given via the rumen cannulas as continuous infusion.

\section{Major minerals}

The calcium carbonate was dissolved directly in the VFA solutions when they were prepared. The calcium phosphate and magnesium sulphate were dissolved separately and added to the VFA solution only when the $24 \mathrm{~h}$ infusate was prepared. The quantities are given in Table I.

\section{Buffer solution}

Buffer solution $(2.51 / \mathrm{d})$ was given containing the quantities in Table 2 which were found by experience to be sufficient to prevent the rumen $\mathrm{pH}$ from dropping below 6.0 . It can be seen that it was necessary to increase the buffer concentration at the high rate of energy infusion, and more was required with increasing proportion of acetic acid, probably because of the increase in hydrogen ions necessary to give iso-energetic VFA solutions. The solution was given as continuous infusion via the rumen cannulas.

\section{Trace minerals}

Since the trace minerals in suspension precipitated the soluble casein it was not possible to infuse them into the abomasum along with the protein. Instead they were injected via the abomasal cannulas once daily. To prevent blockage by precipitated casein, the abomasal catheter was rinsed with water before and after the injection. The quantities used are given in Table $\mathbf{I}$. 
Table I. Quantities of vitamins, trace minerals and major minerals infused when energy intake was twice the maintenance level; below that energy level the quantities were calculated to be proportional to the infusion of energy-yielding constituents

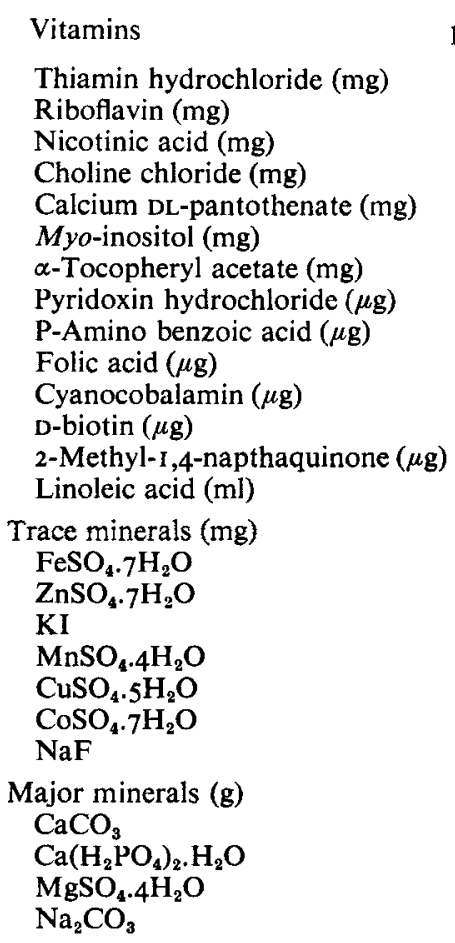

Daily quantity

\begin{tabular}{|c|c|c|}
\hline per kg W $\mathrm{W}^{0.75}$ & for $25 \mathrm{~kg}$ lambs & Method of infusion \\
\hline 0.25 & $2 \cdot 8$ & \multirow{14}{*}{$\begin{array}{l}\text { Dissolved in a solution of } \\
\text { ethanol - water }(30: 70, \mathrm{v} / \mathrm{v}) \\
\text { and mixed with casein for } \\
\text { abomasal infusion }\end{array}$} \\
\hline 1.00 & II $\cdot 2$ & \\
\hline & II $\cdot 2$ & \\
\hline $37 \cdot 50$ & $308 \cdot 0$ & \\
\hline 0.75 & $8 \cdot 4$ & \\
\hline $37 \cdot 50$ & $308 \cdot 0$ & \\
\hline I.00 & $1 \mathrm{I} \cdot 2$ & \\
\hline $100 \cdot 00$ & II 20.0 & \\
\hline 25.00 & $280 \cdot 0$ & \\
\hline $2 \cdot 50$ & $28 \cdot 0$ & \\
\hline $2 \cdot 50$ & $28 \cdot 0$ & \\
\hline 15.00 & $168 \cdot 0$ & \\
\hline 125.00 & $1400^{\circ} 0$ & \\
\hline 0.25 & $2 \cdot 8$ & \\
\hline $43 \cdot 80$ & $490 \cdot 5$ & \multirow{7}{*}{$\begin{array}{l}\text { Given as suspension once } \\
\text { daily into the abomasum }\end{array}$} \\
\hline 2.53 & $28 \cdot 3$ & \\
\hline $2 \cdot 34$ & $26 \cdot 2$ & \\
\hline $1 \cdot 23$ & $13 \cdot 8$ & \\
\hline $1 \cdot 12$ & $12 \cdot 5$ & \\
\hline 0.46 & $5 \cdot I$ & \\
\hline I. 59 & $17 \cdot 8$ & \\
\hline $1 \cdot 08$ & $12 \cdot I$ & \multirow{2}{*}{ Dissolved in VFA solution } \\
\hline 1.02 & II $\cdot 4$ & \\
\hline 0.28 & $3 \cdot I$ & \\
\hline 0.572 & $6 \cdot 4$ & $\begin{array}{l}\text { Used as } 2 \mathrm{M} \text { solution to } \\
\text { dissolve casein }\end{array}$ \\
\hline
\end{tabular}

W, body-weight.

Table 2. Level of buffer minerals infused consisting of sodium bicarbonate (0.62), potassium bicarbonate $(0.32)$ and sodium chloride $(0.06)$; the mineral mixture was infused according to volatile fatty acid (VFA) solution and level of infusion at maintenance $\left(450 \mathrm{~kJ} / \mathrm{W}^{0.75}\right)$ and twice $\left(900 \mathrm{~kJ} / \mathrm{W}^{0.75}\right)$ maintenance energy intake

\begin{tabular}{|c|c|c|}
\hline \multicolumn{3}{|c|}{$\begin{array}{l}\text { Proportions of VFA } \\
(\mathrm{mmol} / \mathrm{mol})\end{array}$} \\
\hline Acetic & Propionic & Butyric \\
\hline 350 & 550 & 100 \\
\hline 450 & 450 & 100 \\
\hline 550 & 350 & 100 \\
\hline 650 & 250 & 100 \\
\hline 750 & 150 & 100 \\
\hline
\end{tabular}

\begin{tabular}{|c|c|c|c|}
\hline \multicolumn{4}{|c|}{ Level of infusion } \\
\hline \multicolumn{2}{|c|}{$\mathrm{g} / \mathrm{W}^{0.75}$} & \multicolumn{2}{|c|}{ For lambs weighing $25 \mathrm{~kg}$} \\
\hline $450 \mathrm{~kJ} / \mathrm{W}^{0.75}$ & $900 \mathrm{~kJ} / \mathrm{W}^{0.75}$ & $450 \mathrm{~kJ} / \mathrm{W}^{0.75}$ & $900 \mathrm{~kJ} / \mathrm{W}^{0.75}$ \\
\hline $6 \cdot 27$ & $14 \cdot 34$ & $70^{\circ} 2$ & $160 \cdot 6$ \\
\hline $6 \cdot 6 I$ & $15 \cdot 12$ & $74 \cdot 0$ & $169 \cdot 3$ \\
\hline $6 \cdot 94$ & 16.02 & $77 \cdot 7$ & $179 \cdot 4$ \\
\hline $7 \cdot 39$ & 16.91 & $82 \cdot 8$ & $189 \cdot 4$ \\
\hline $7 \cdot 84$ & 18.03 & $87 \cdot 8$ & $201 \cdot 9$ \\
\hline
\end{tabular}

W, body weight. 


\section{Vitamins}

The solution of vitamins was mixed daily with the casein after the casein was dissolved with sodium carbonate. The quantities given are shown in Table I. Retinoic acid, cholecalciferol and $\alpha$-tocopheral were given as intramuscular injection. Vetrivite ( $\mathrm{ml}$; C-Vet Ltd, Minster House, Western Way, Bury St Edmunds, Suffolk) containing $(/ \mathrm{ml}):$ I5o mg retinol, I. $875 \mathrm{mg}$ cholecalciferol and $50 \mathrm{mg} \alpha$-tocopheryl acetate, was given every I $5 \mathrm{~d}$.

\section{Management}

The level of infusion was aimed at a total of $900 \mathrm{~kJ} / \mathrm{W}^{0.75}$. The animals were cannulated and approximately 2 weeks were allowed for post-surgery recovery after which the infusion began. The lambs had free access to dried grass but when infusion reached the intended level little if any was consumed, and it was subsequently removed. Drinking-water was always available. The intended level was reached during a period of 2 weeks in the instance of maintenance energy $\left(450 \mathrm{~W}^{0.75} / \mathrm{d}\right)$ and 3 weeks for the twice maintenance energy level $\left(900 \mathrm{~W}^{0.75}\right)$.

\section{DISCUSSION}

The problems of rumen $\mathrm{pH}$, electrolyte imbalance, etc. were essentially overcome when it was realized that only a buffer solution was required and that attempts to partially neutralize the VFA were only creating problems of electrolyte imbalance. This is in complete agreement with the findings of Ash \& Dobson (1965), namely that the VFA are absorbed as free acids so that a buffer is only required to neutralize or maintain the $\mathrm{pH}$ between 6 and 7 of the VFA actually present in the rumen and not the VFA after absorption. The blood measurements of minerals, ketones and glucose have been in the normal range except for the inorganic $P$ which was generally elevated. In long-term experiments with lambs of up to 3 months duration the post-mortem findings have essentially been normal though sometimes an enlargement of the kidneys was noted. Growth rates of $150-200 \mathrm{~g} / \mathrm{d}$, with no apparent differences between infusion mixture have been noted. A common feature was a somewhat regressed and thin-walled intestine and a large amount of cellular debris in the ventral sac of the rumen, which presumably consisted of abraded epithelial cells. No faeces were produced, except during the first few days after solid feed was withdrawn. The lambs which were slaughtered when the infusion was terminated had fat of normal composition and colour and the amount of fatness was similar to those of normal lambs. On occasions when it was desired to adapt the lambs to solid food again, normal intakes could generally be achieved in a period of 8-10 d, provided the lambs were incubated with a rumen fluid sample from another sheep.

The use of the technique in the study of protein and energy utilization in ruminants will be reported elsewhere.

The authors wish to express their gratitude to $\mathrm{Dr} \mathrm{D}$. Scott for many useful discussions during the development of this method. 


\section{REFERENCES}

Armstrong, D. G. \& Blaxter, K. L. (1956). Proc. Nutr. Soc. 15, i. Armstrong, D. G. \& Blaxter, K. L. (I957a). Br. J. Nutr. II, 247. Armstrong, D. G. \& Blaxter, K. L. (1957 b). Br. J. Nutr. 11, 413. Ash, R. W. \& Dobson, A. (1965). J. Physiol, Lond. x69, 39.

McKenzie, J. D. \& Kay, R. N. B. (1968). J. Sci. Technol. 14, I 5. Martin, A. K. \& Blaxter, K. L. (1963). Proc. Nutr, Soc. 22, xiv.

Ørskov, E. R. (1977). Wld Rev. Nutr. Diet. 26, 225.

Ørskov, E. R. \& Allen, D. M. (1965), Br. J. Nutr. 20, 519.

Tao, R. C. \& Asplund, J. M. (1975). J. Anim. Sci. 41, 1653.

\section{EXPLANATION OF PLATE}

(a) A section of the rumen wall; note the flat, well developed papillas, (b) the plastic scrubbers of which six were inserted via the rumen cannulas. They were the normal domestic type (Spong \& Co. Ltd, Crompton Close, Basildon, Essex, England). 

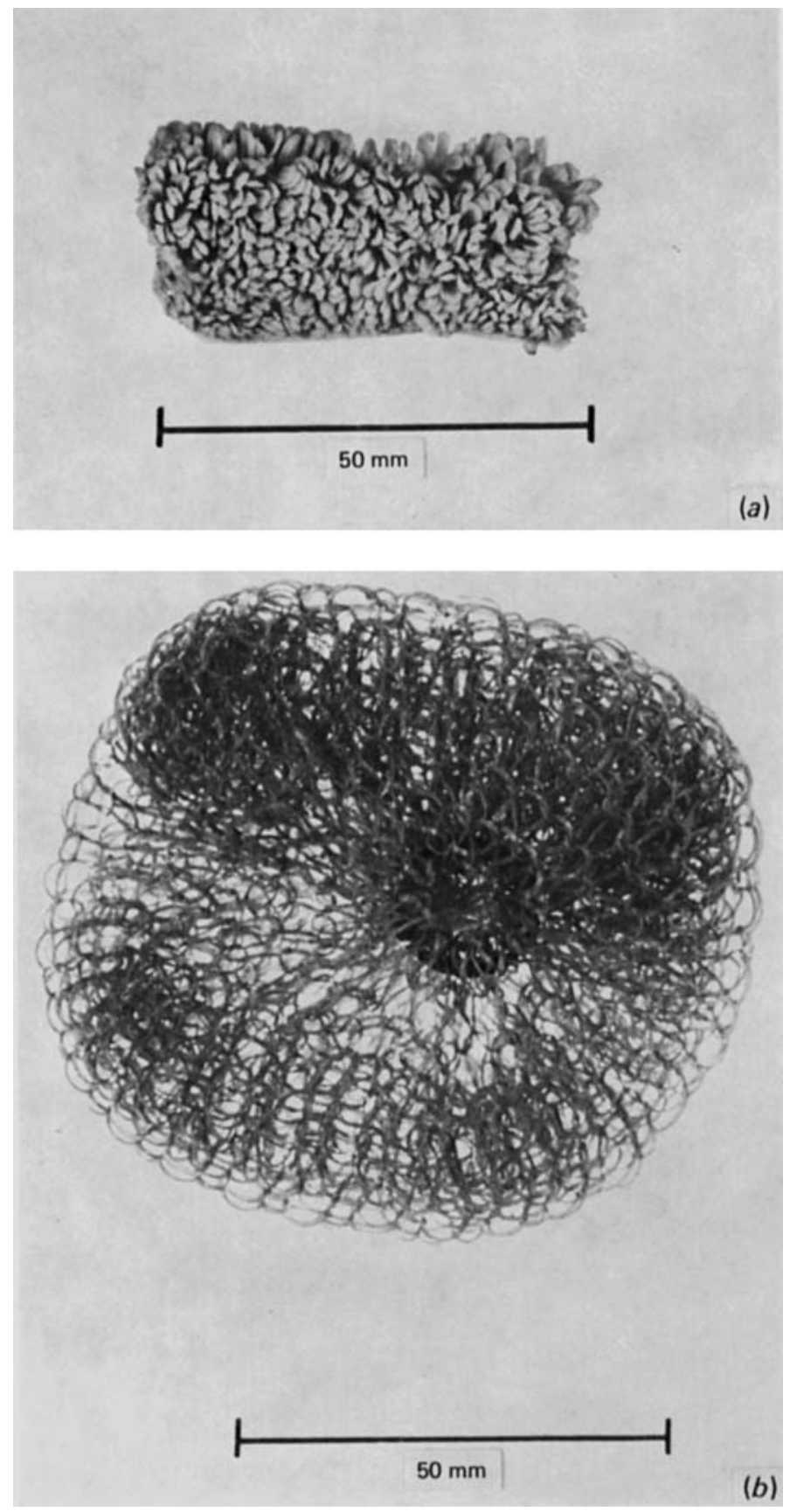